\title{
REFLECTIONS of MINIMALISM ON CONTEMPORARY CERAMICS
}

Kemal TİGÖL*

\begin{abstract}
Minimalism appeared in the late "60s in United States and deeply affected art environment in this period. Besides, it has an important place in the art history as the latest effective attack of Modernist movements. After Second World War, art was influenced by fundamental revolutions in social structure, thus Minimalism takes place in the art area as an alternative attitude against to Abstract Expressionist movement. At first, Minimalism was strongly criticized and resisted but later accepted by the critics and audience.

During Modernism, ceramics is freed from its traditional roots and has a contemporary appearance with its own special qualities both formally and conceptually. Ceramics and Minimalism appear to be two separate and alien phenomena, which at first glance are temporary; their relations with each other are not perceived at once. This impression also carries a margin of reality. This study aims to investigate Minimalism in the historical context and its reflections on the Contemporary Ceramics. Paper also shows valuable ceramic art forms related with minimalist idea and esthetics. On one hand, ceramics with all the original sensations and emotions of the past, on the other hand Minimal Art as cold, distant and restrained. This study aims to examine the practical interaction of this union unnamed in the history of art.
\end{abstract}

Keywords: Ceramic, Minimalism, Ceramic Art, Contemporary Ceramics, Modern Ceramics

\section{Introduction}

The historical emergence of Minimal Art; Independent, sometimes even disjointed artist practices in minimalist movement and their resistance towards American Abstract Expressionism can be considered as starting point. Concentration on reductive and pure geometry, of Minimalism also makes it necessary to say something about the art movements before minimalism such as Constructivism, Suprematism and De Stijl in Modern Art. Minimalism, as Judd noted in one of his article, "was born to reject European past of the art history and its ongoing efforts since the Renaissance". In this respect Minimalism adopts a radical attitude. The coolness of Minimalism has created an antithesis to the powerful and enthusiastic wave of Abstract Expressionism in the 1950s.

There is a relationship between Minimalism and ceramics that has no definite boundaries. However the precise, clear, and purist attitude of Minimal Art which deliberately destroys individual emotions and envisages a formal reduction in artistic expression; has been adopted by some ceramic artists today and influential in their art work. "Expressive effects", which are difficult to control, arise from the nature of ceramics and kiln process; turn into elements that must be eliminated in the work of artists, who adopt minimalist attitude. This stance, which forces the borders of the material, has led to the creation of formally and conceptually new way of expression.

* Associate Professor.Dr.Akdeniz University, Faculty of Fine Arts, Department of Ceramics, ceramist75@hotmail.com 
Within 20th century art movements, in order to comprehend Minimal Art, that creates a new art form with a reactive approach by excluding the art tradition, it is necessary to examine the post-World War II art scene. In the 1960s, States became a symbol of capital power of the polarized world, due to the cold war and created a model that exports new roles in politic, economic and social sense. This politic and economic power reflected to the art and independent American spirit wished to get rid of European art tradition, found itself in search of a brand new, free art.

During this period, as being interested in subconscious and philosophy of Far East, Motherwell and Jackson Pollock have created an avant-garde and abstract American Art in the form of independent, diverse, large scaled, free expressional techniques. Nationalist, realist and social realist paintings of Post-war period have remained secondary to the abstract art. In New York, with the participation of names such as Philip Guston, Barnet Newman, Adolph Gotlieb, Franz Kline, Mark Rothko, Ad Reinhardt, Hans Hoffmann, the New York Ecole, "New York School", has emerged.

\section{Minimalism Concept and Minimal Art Phenomenon}

The term of "Minimal Art", which was first used by thinker Richard Wollheim in 1961 for "the most reduced-content art", was mostly used for three dimensional works, sculptures. However, it also describes paintings starting in 1960's within the sense of wide spreading art in USA. According to another source, "Barbara Rose mentioned a new artistic tendency in her article with 'ABC Art' title which was published by Art in America, in October 1965. A nomenclature such as "ABC Art" (basic art) was not accepted, but the word "minimum", which she had used, has vitalized concept of "Minimalism" (as cited in Batur, 1995, s.84).

The definition of the Minimal process, which can be perceived as a movement that uses all potential art sources in the fields of visual, auditory, literary and other art disciplines in post-war America, has caused some debates in art circle. An opinion characterizes Minimalism as the "end of the Modernism" and thus a transitional process between modern and post-modern.

Minimalism, a kind of sculpture-focused abstract art form, was especially influential in the American art scene at the end of the 1960's and in the 1970's. To express the simplicity of this type of art form, Minimalism that is also called "ABC Art", shows a geometric and reductionist approach in sculpture and painting. In this reductionist approach, formalism reaches its extreme expression, because the form becomes content. Minimalism, pioneered by artists such as Carl Andre, Dan Flavin, Donald Judd, Sol Le Witt, Robert Morris, Richard Serra and Anne Truitt, defended extreme simplicity and objective approach in form (Figure 1). Other terms such as ABC Art, Cool Art, Primary Structures, and Rejective Art have been asserted to verbalize these practices.

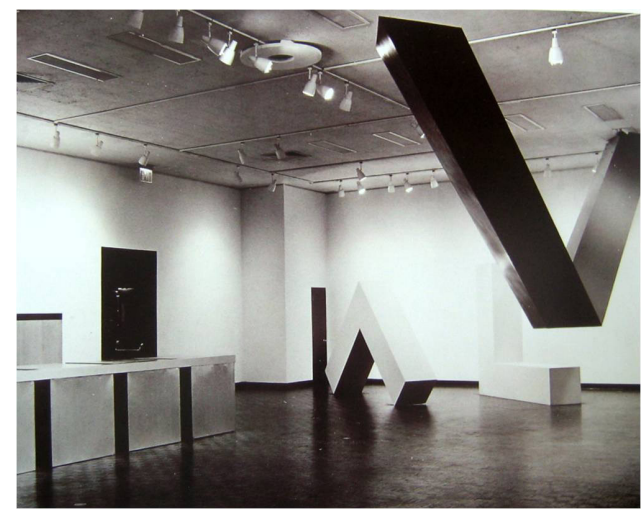

Figure 1: "Primary Structures", Jewish Museum, New York, 1966. 
Minimalists have argued that an art work should evoke only itself; therefore they try to purify their art work from any non-visual associations. Although, Minimalist artists made great efforts to be integrated with urban life, their creations shocked the people and were not easily accepted by the society in general. Their arts are tacit, incomprehensible and elitist. While purchase of Carl Andre's construction which was made up of bricks, by Tate Gallery sparked great reaction in Great Britain (Figure 2); Richard A. Serra's famous sculpture "Titled Arch", which was located in a square in New York, was removed from its place as a result of the collected signatures (Figure 3). Minimalism, is the first international art movement that is completely pioneered by USA born artists.

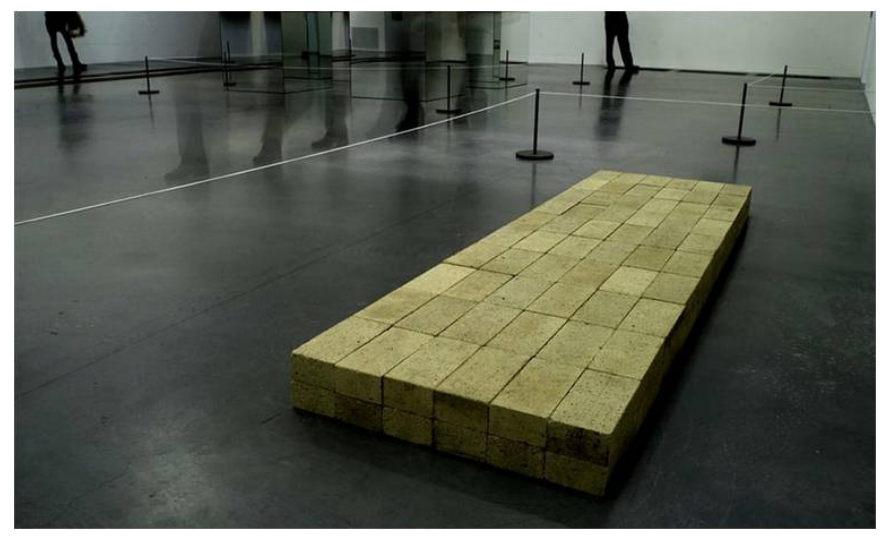

Figure 2: “Equivalent VIII”, Carl Andre, Tate Modern, 1966.

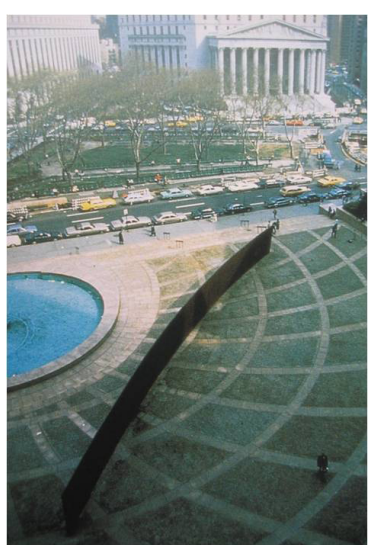

Figure 3: "Tilted Arc", Richard Serra, 1981.

In fact, the concept of Minimal Art has long been an ideational proposal for the works of Russian constructivists like Tatlin, Rodchenko, Malevich and De Stijl group painters like Mondrian and "Hard edge" painting approach. Stella is regarded as one of the most important pioneers of Minimal Art with the series of "Black Paintings" which he painted in 1959-1960 (Figure 4). "What you see is, what you see"; Stella's this statement explains everything (Meyer, 2001, p.6-9).

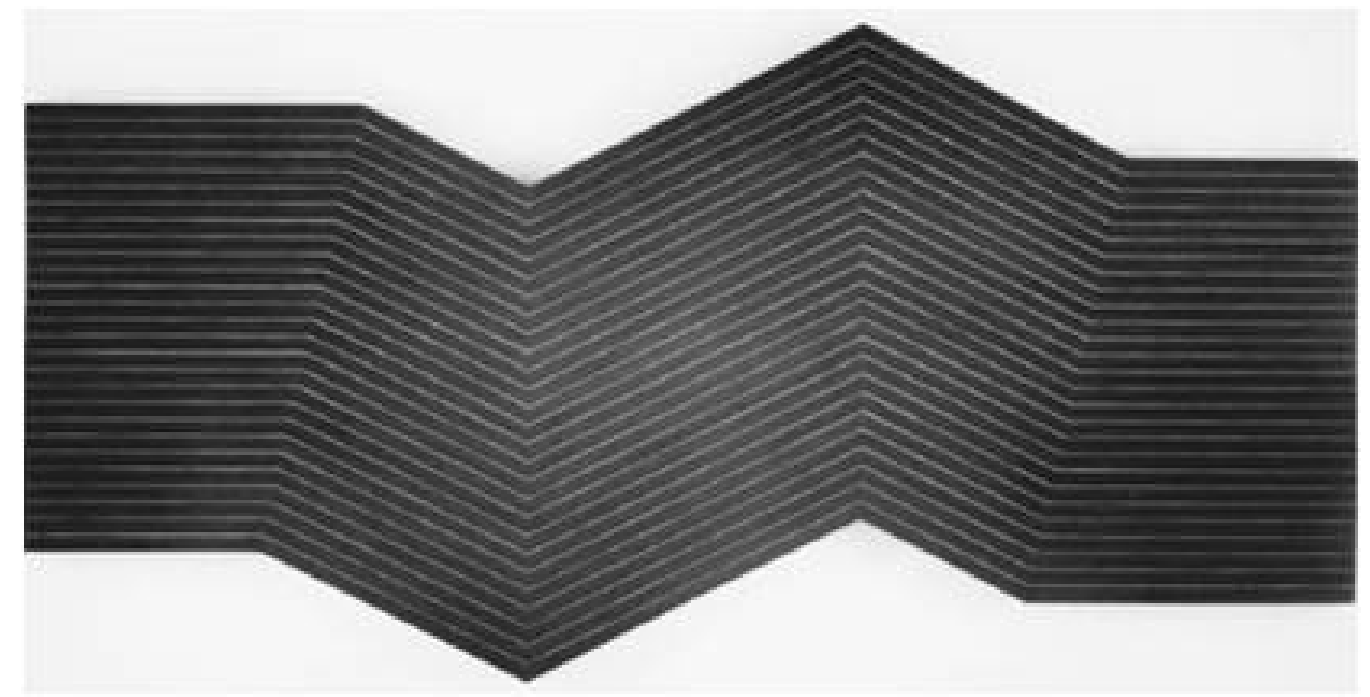

Figure 4: "Nunca Pasa Nada" Frank Stella, 1964, oil on canvas, 270x540 cm. New York, The Lannan Foundation. 


\section{Minimal Tendencies in Contemporary Ceramic Art}

The ceramics, which seemed not to take much of a share in the modernist movement, made the main move in the postmodern period. In the 1960's, while painting and especially sculpture were deeply influenced by New York-based Minimalism; in west coast of United States, ceramic created Funk Art which is a diametrically opposite discourse of minimalism and identifies directly with the ceramic. It is noteworthy that after Abstract Expressionism, American ceramic artists unlike painters and sculptors, haven't been fascinated by powerful effects of Minimalism, even have created a completely independent expression form from this movement. When we consider the evolution of ceramics, as in painting and sculpture, it is seen that the abstractive, constructivist, abstract expressionist tendencies have come to the fore in the process. However, minimalist tendencies in ceramics have begun to manifest themselves after the 1960's when Minimal Art's strongest period, and still continue today.

Ceramists embraced by Minimalism, have been impressed by Ludwig Mies van der Rohe's approach "less is more" which has been one of the Minimalism's mottos. Due to the nature of the material, the fire always tends to emphasize powerful effects; -ash sparkles formed during the firing process, kiln drops, metallic lusters, flame marks, color change by thinning at the edges of the form- all of these effects, which the minimalists have avoided, tend to create very vivid and rich effects on the surface. For the ceramists who have adopted minimalist approach, these elements, which are the essence of the ceramics, turn into factors that need to be carefully prevented or controlled.

The best way to understand minimal trends in today's ceramics will be the discussion about artists' work. At this point, it seems that the artists handle the subject with different forms of expression and technical practices. In these samples, it is observed that the ceramic material and the opportunities of expression constitute a language that is almost identical to the artists, in this minimal world.

Spanish artist known with his geometric abstraction Enrique Mestre is very important figure in the field of minimalistic ceramics. Mestre first, studied painting at the San Carlos Fine Arts School in Valencia. Later he studied ceramics at Manises School. Mestre's tendency is based on influences of far eastern ceramics, high temperature firing techniques without surface decoration with traditional methods. Mestre, who prefers an abstract geometric expression in his works, when describing his commitment to geometry, he states that having worked on graphic design, based on exact rational parameters, plays an active role in his works. It is observed that internal and external spaces and straight edge geometric volumes obtained by eliminating all ornamental elements play crucial roles on his sculptures with architectural references made in 1990's (Camps, 2001, p.41-45), (Figure 5).

What makes Mestre's architectural ceramic works minimal is that he completely rejects the ornamental approach and the use of monumental simplicity in his works. In this respect, his works have similar attitude with the works of Donald Judd. 


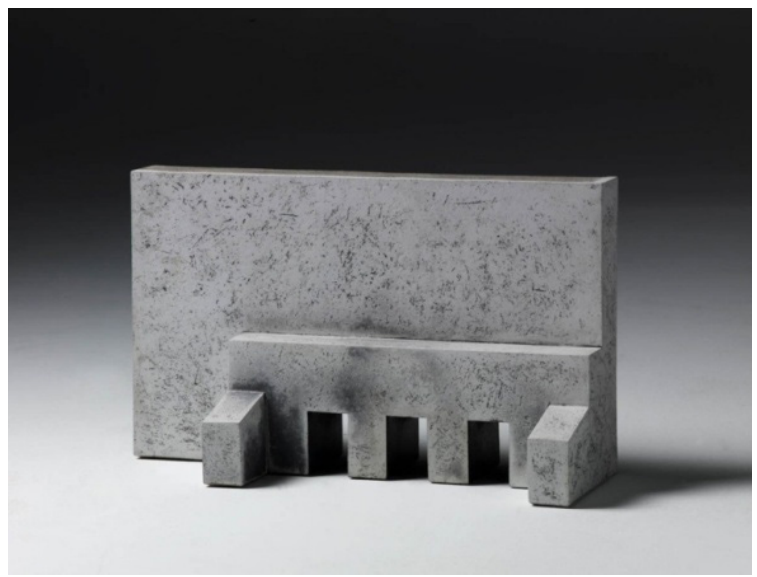

Figure 5: "Sculpture", Enrique Mestre, Stoneware with calcined clay, 33x56x19 cm. 2003.

As an example of the transformation of minimal expression into vessel form, the bowls of Alev Ebüzziya Siesbye immediately comes to mind (Figure 6). "Siesbye, who was born in Turkey, has gained her ceramic experience in Denmark, lives in Paris now and continues her work in her atelier, is one of the first "new minimalist artists" Alev Ebüzziya Siesbye is known with her simplicity of forms she has been working on since 1960's, her commitment to a single form and her bowl form, on which she has made only minor changes throughout her career and which has become her signature (Vecchio, 2001, p.42). Siesbye, with her own minimalist attitude, offers a privileged position to the bowl form, which is one of the most typical forms of traditional ceramics. Siesbye sometimes uses single or double thin bands, on the mouth and the neck of the form to reveal the specific sensitivity of stoneware clay's textured surface. These ceramics, which are far from the basic characteristics of the traditional stoneware ceramic (solid, dark colored, thick-walled), are iconized in contemporary ceramic art with the other works of artists like Lucie Rie and Richard DeVore who put forward the bowl form with their unique creative vision.

The minimalist approach in Alev Ebüzziya Siesbye's works is the idea of the destruction in perception of "traditional ceramic bowl". That is much more than just the simplicity in understanding of form, her color palette and avoiding exaggerated surfaces. Siesbye offers a new "bowl" suggestion by reducing the function as the main element.

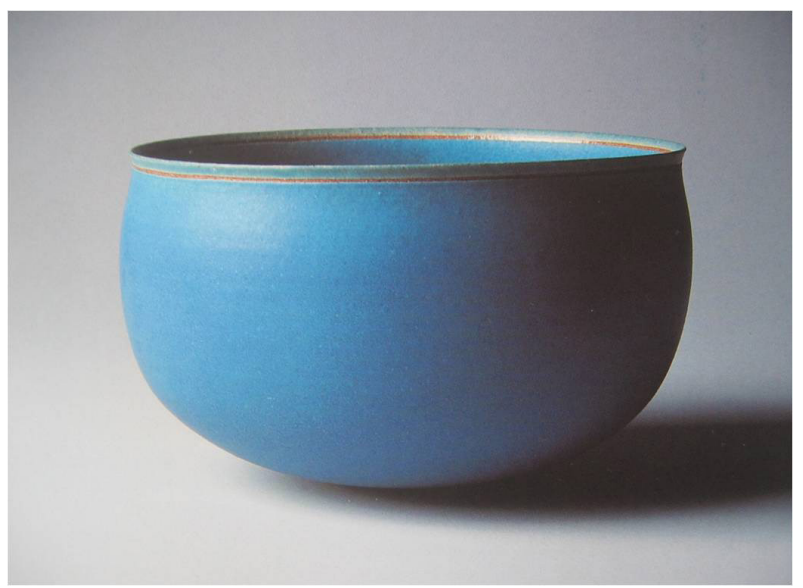

Figure 6: "Bowl”, Alev Ebüzziya Siesbye, h.21,5 cm. Ø: 35.5 cm., 1987. 
Copenhagen born artist Bodil Manz, studied ceramics first at the "School of Arts \& Craft in Copenhagen", later she continued at the "Berkeley University in California" in the USA. Manz's works have been done with a very sensitive approach. Her cylindrical porcelain pots are so thin and semi-transparent that they almost resemble oily paper (Figure 7-8). The sense of fragility at her works is deceptive. In the works of Manz who produces extraordinary works by using semi translucent feature of the porcelain; forms are strong and flexible. The decoration technique in her works is also remarkable. Manz carries out all lines, color blocks, and geometric schemes in her decorations by using overglaze decal technique in order to avoid the pictorial sensitivity and maintain the graphical effect.

Bodil Manz's works presents us with the deepest and purest form of geometry. This minimal geometry is far from perspective and mostly two-dimensional. The use of color fields, split parts, lines and stripes in the works are completely integrated into the form. Intelligent use of the inner and outer surfaces of the cylinder, one of the simplest ceramic forms, emphasizes the phenomenon of space in ceramics.

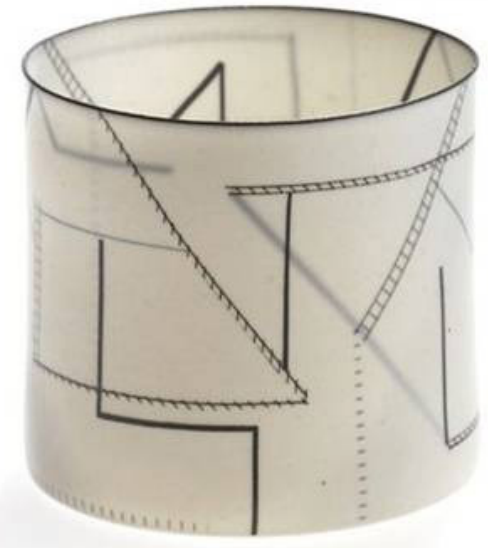

Figure 7: "Architectural Volume", Bodil Manz, Porcelain, 2004.

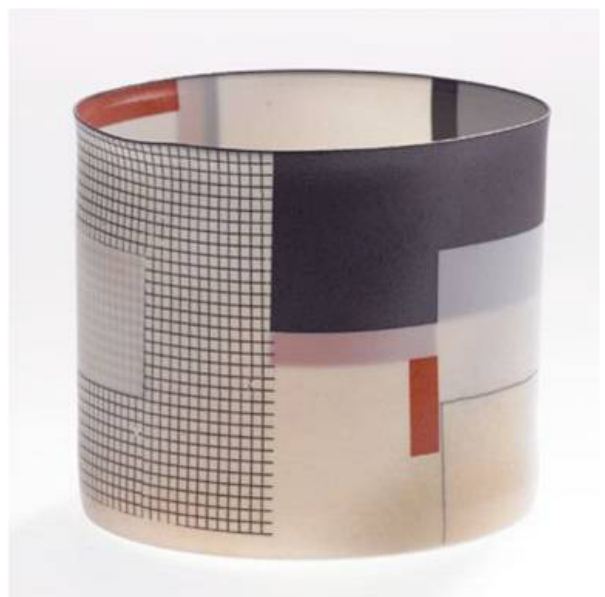

Figure 8: "Architectural Volume", Bodil Manz, Porcelain, h12 cm., d14cm. 2006.

The Dutch artist Wouter Dam uses similar methods as Alev Ebuzziya Siesbye to create a minimal expression. Although his forms are covered with strong, saturated and monochrome glazes, Dam allows clay to appear at the edges of the form in order to reveal the sharpness and the impressiveness of it (Figure 9). What makes his works different from traditional attitude in pottery? The forms of Dam give impression like turning their around and disappearing of the foot parts, hereby they look like double open-ended tubes (Figure 10-11). Anyway, these forms deal with the surrounding of space as all vessel forms has done (Vecchio, 2001, p.43). However, when the surrounding of space ends with a ground in well-known traditional form of pots, it becomes possible to enter in Dam's works.

The purist attitude and perfectionist approach in the artist's works brings Wouter Dam's works closer to minimalist idea. These altered and varied forms have sharp edges, striking colors and a harsh appearance that we are not used to in ceramic. These ceramic forms, produced by hand on a potter's wheel, give the feeling of produced industrially with the help of a machine. In this respect, works of Dam establishes a close relationship with Minimal Art. 


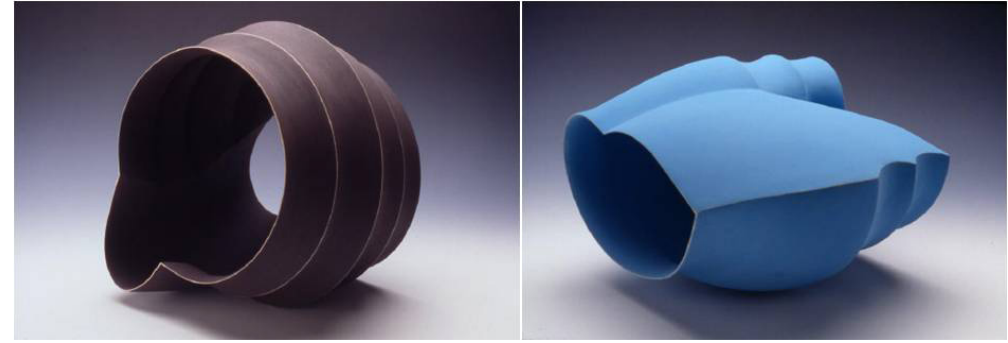

Figure 9: "Black form with white striped “, Wouter Dam, 12x12x$9.5 \mathrm{~cm} ., 2000$

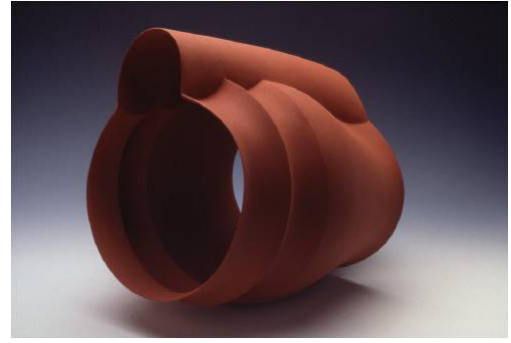

Figure 11: "Red form", Wouter Dam, $12.5 \times 10 \times 11$ in. 2000.

The reductionist approach appears as an important attitude in minimalism. Shows such an attitude in his works German artist Michael Cleff studied on both sculpture and ceramics. Cleff works with a limited number of formal elements and associates them to make new variations. His minimalist approach is based on the use of repetitions of basic geometric forms -diagonal, square, rectangular, elliptical- and monochromatic colors (Dewald, 2004). Cleff's geometric forms and multi-narrated domed forms remind architectural structures at first glance. However, it would be a mistake to consider his sculptures are representations of real buildings. What cannot be denied, on the other hand, is the archaic force and astonishing monumentality which these sculptures radiate (Mönig 2001). The works of Cleff, do not only relate to the space around, but also define the space within themselves by shaping the light entering through their open spaces. It can be said that Cleff's minimalist style is simple but not cool.

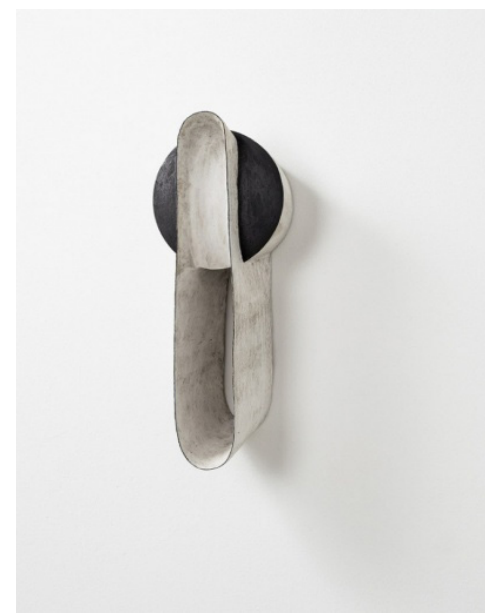

Figure 12: "Over the Ground", Michael Cleff, h: $56 \mathrm{~cm} ., 2014$.

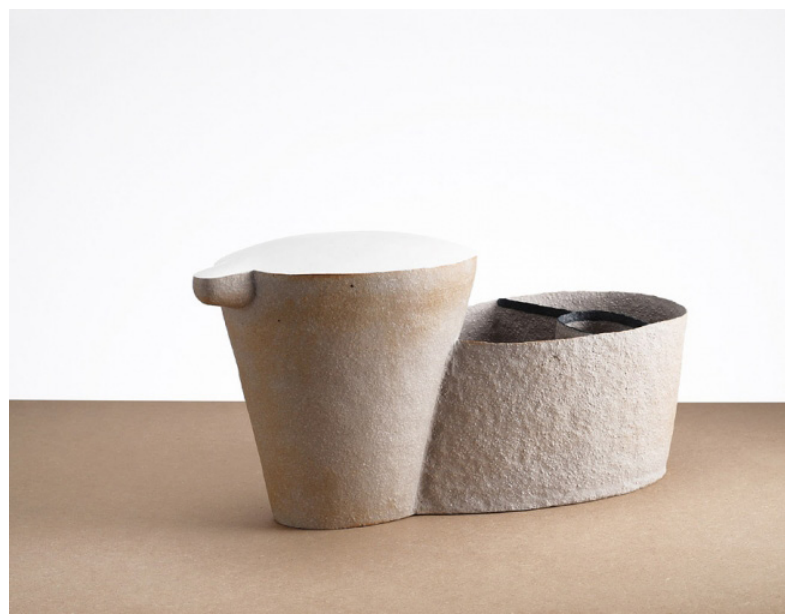

Figure 13: "Over the Ground", Michael Cleff h: 31 cm., 2012.

Nicholas Rena born in London in 1963, he completed his master's degree in architecture at Cambridge University in 1986 and worked as an architect in various projects until 1992. Rena entered the Royal College of Art in 1993 to get a master degree from ceramic department. Within a short period of time, Rena's works attract a remarkable attention. His fascinating sculptures with their thick-walled, inkcolored velvety surfaces and minimalist styles refer to the architecture and the anthropomorphism at 
the same time (Tizgöl, 2008, p.110). (Figure 14).

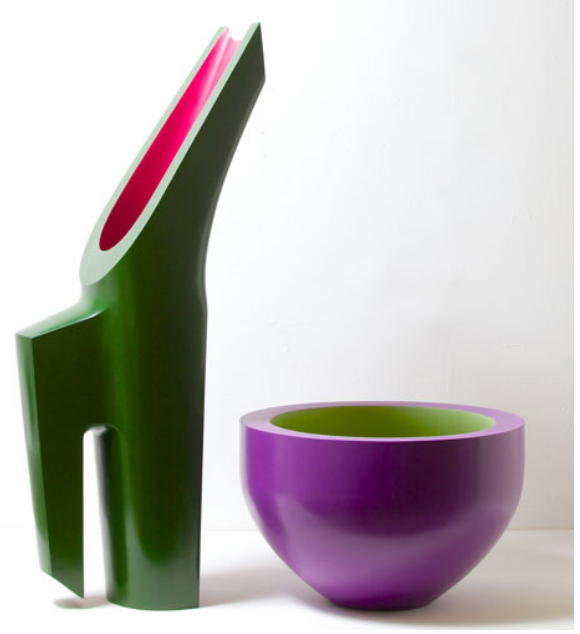

Figure 14: "The Harmony of the Year", Nicholas Rena,

Ceramic painted and polished, bowl $27 \mathrm{~cm}$ high, pitcher h. $85 \mathrm{~cm} .2013$.

Ken Eastman, who is known for his works far from traditional pottery, is another artist who adopts minimal touches. Eastman born in 1960, studied ceramics first at Edinburgh College of Art and then Royal College of Art, London. When Eastman is asked about his thoughts on his works, he explains briefly his purpose: "to do things I have never seen before". In his latest works, sometimes by waving the bottom part of the form in a different way or by taking the advantage of the tension arising from the curved side walls, he changes all the anticipations we have formed for the pot form (Figure 1516-17-18).
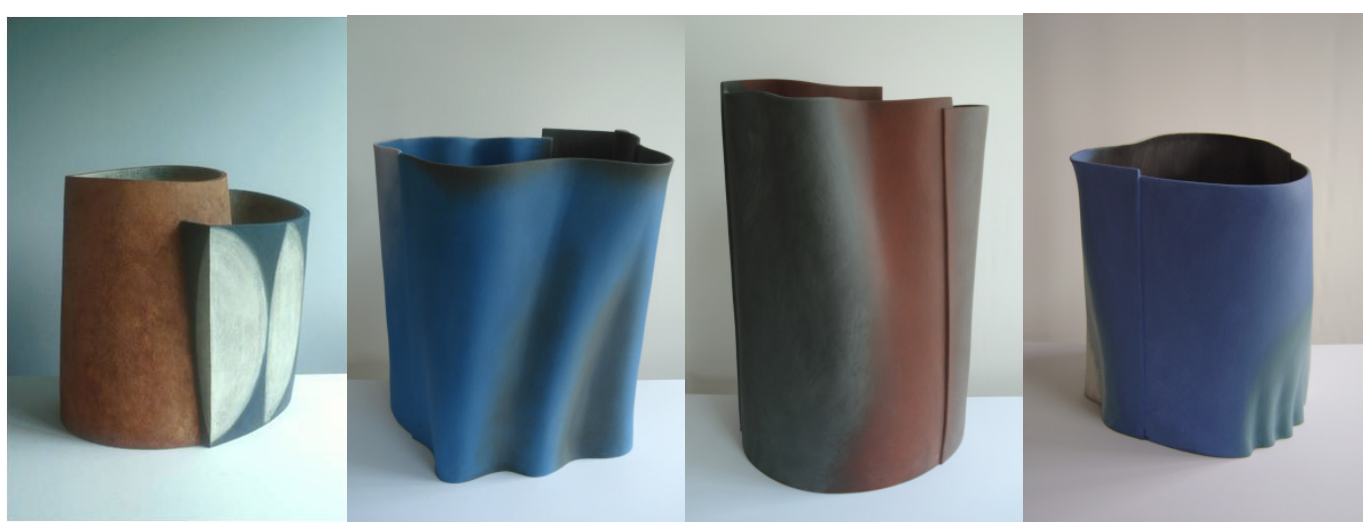

Figure 15: Pot, Ken Eastman, h:35 cm., 1995 - Figure 16: Chesapeake Bay, Ken Eastman, h:62 cm., 2005.

Figure 17: Don’t let go , Ken Eastman, h:71 cm. , 2005 - Figure 18: Nova, Ken Eastman, h:40 cm. , 2005.

Martin Smith is one of the most important names in contemporary British ceramics. The most important characteristic of the artist is to establish an interactive relation between architecture and ceramics. In the 1980s, Smith was highly influenced by Italian Renaissance architecture. Today, 
Smith's sculptures still maintain this close ties with architecture. Artist creates his forms by using terra-cotta brick clay and after firing process he cuts them with a diamond-tipped saw until an image of red velvet is obtained. Then he covers the inner surface of the form with gold or platinum foil as a hedonist approach (Figure 19). This action of the artist can be considered as a combination of two opponent things: valuable and ordinary. It can be said that; visual constraint and allusive contradictions, arising from the combined use of terra-cotta -most used building material of the world- and valuable items such as gold, are indications of the ironic attitude of Smith's works.

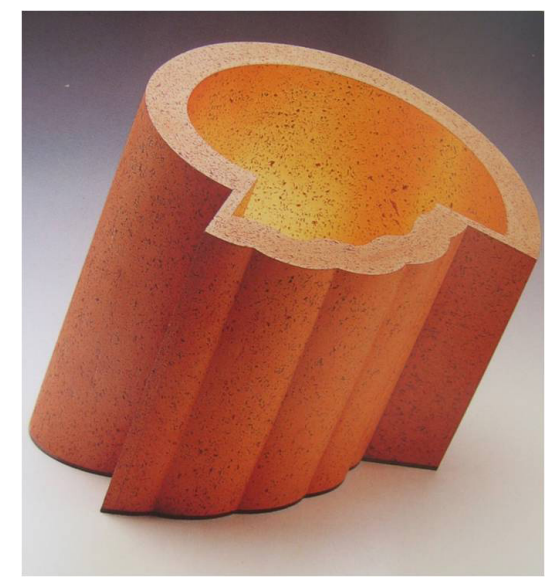

Figure 19: "Shift and Progression, Martin Smith, Terracotta, slate, gold leaf, $30.5 \times 35.5$ cm. 1994.

Being known as one of the most important contemporary celadon masters, Sueharu Fukami is in search of pure surfaces in his large-sized sculptures and vessels build by slab. In his works, the perfect application of glaze as well as the impressive minimalist attitude is remarkable (Figure 20). In 1975, Fukami began to concentrate on qingbai glazes, and in the 1980s he developed high-pressure casting technique to create his own unique forms. The Artist stated that he has developed this technique to prevent warping and hand marks that occur during the firing process. When, such unexpected modifications on the form or glaze due to the firing process are considered as acceptable in traditional Japanese ceramic art, even appreciated; Fukami does not accept the differences between what he designs in his mind and final image of it after the kiln process. So Fukami has struggled with this problem for years to get a perfect approach to his art.

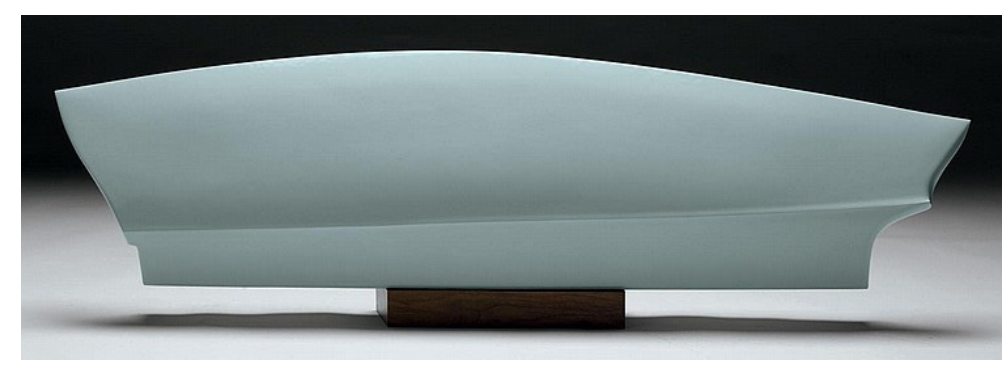

Figure 20: Hope, Fukami Sueharu,

Horizontal mold-case sculpture; celadon glazed porcelain, L: $130.8 \mathrm{~cm} .1990$.

Doris Kaiser's artistic approach is controversial; it allows inquiries and feelings to be questioned from different angles. The special expression of Kaiser's works is derived from the usage of plaster and clay combination for creating the contrast (Figure 21-22-23). 


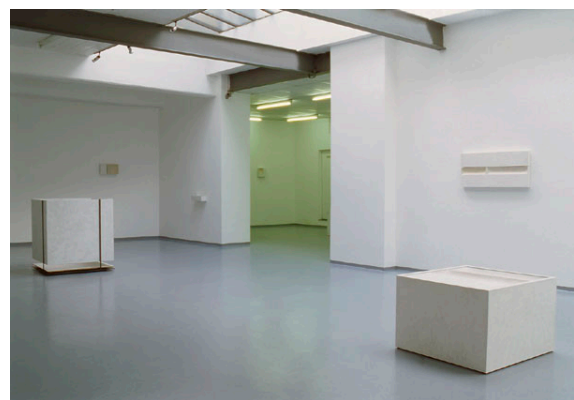

Figure 21: Doris Kaisel, Galerie Christian Fochem , Krefeld, 2004

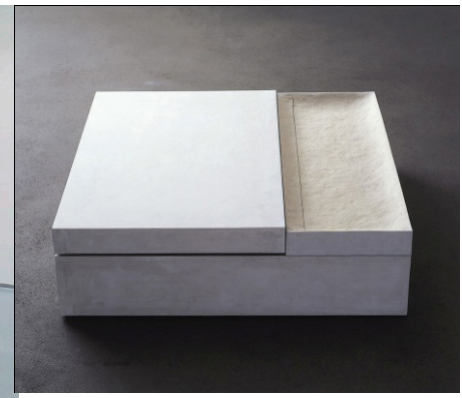

Figure 22: "Untitled", Doris Kaiser, fired clay, plaster, $23 \times 76 \times 74$ cm. 2000.

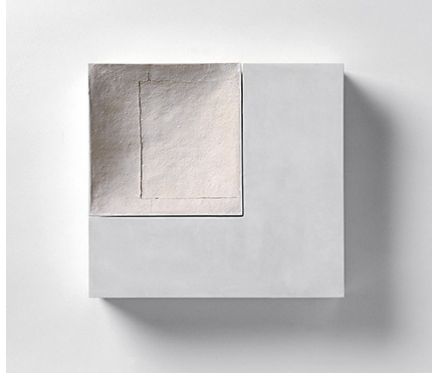

Figure 23: "Untitled", Doris Kaiser, fired clay, plaster, $25 \times 25 \times 7$ cm. 2003.

British artist David Binns uses composites made from pigmented refractory materials such as grog, glass, zircon, mullite and mixtures of natural minerals in his works (Figure 24). Inventing special composites for his own work is the result of being a member of the academy. His researches that concentrate on material and lead to self-improvement constantly form the basis of his artistic expression.

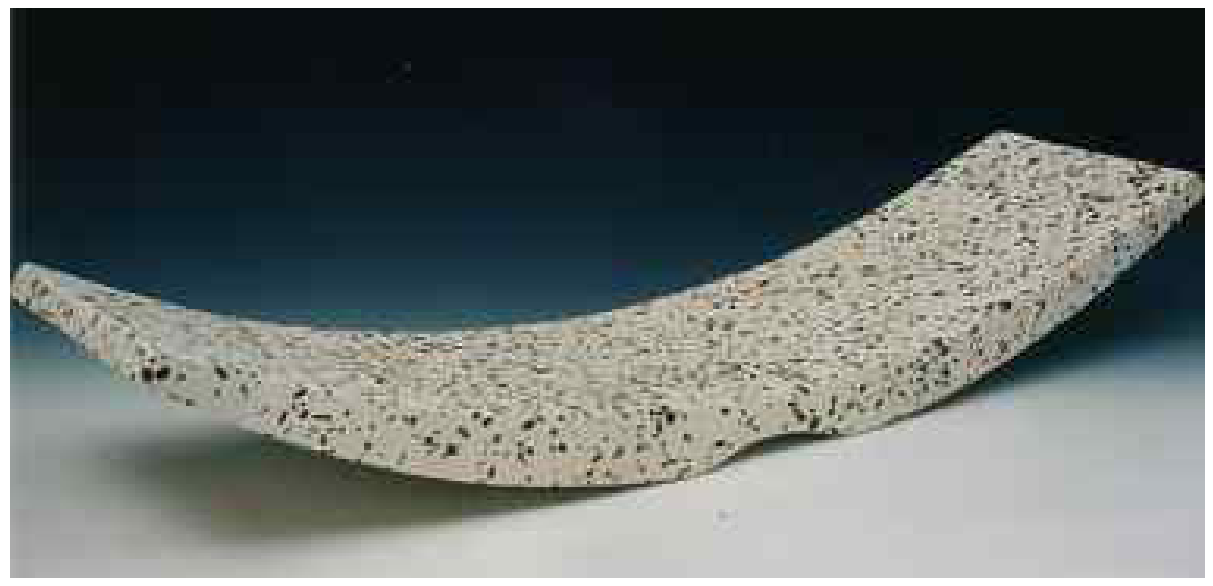

Figure 24: Long White Form, David Binns, $77 \times 20 \mathrm{~cm}$, porcelain \& beach pebbles.

Brian Harper makes precise, not rigid but exciting, geometric, large-scaled, monochromatic sculptures by using basic shapes such as cylinders, cubes and spheres (Figure 25). His unique approach to material and tradition results in visually breathtaking and intriguingly forms of art. "Since Harper's works do not look like familiar ceramic forms characteristically, they show noticeable awareness for ceramic minimalism or Post-Minimalist sensibility. His terra-cotta sculptures are the privileged examples of formalist reduction in contemporary ceramics" (Welch, 2006, p.53). 


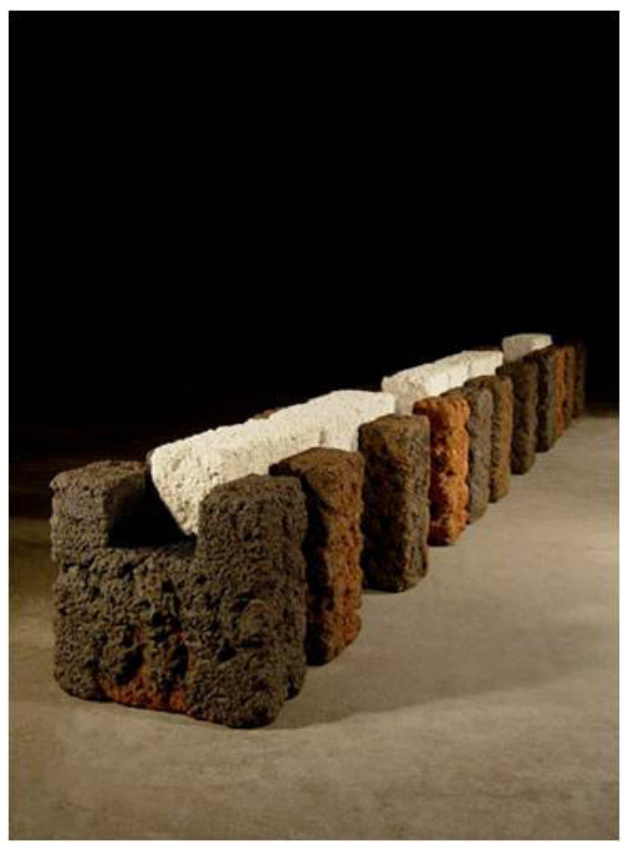

Figure 25: Brian Harper, "New Myth Series "Boundary", 26 in.22in.x21ft, carved clay and porcelain.

\section{Conclusion}

In this study the historical process of minimalist movement which appeared in the U.S. in the early 60 's and then had a great impact all over the world, and what interactions it creates in contemporary ceramics are examined. In the first part of the study, the conceptual background of minimalism is examined and its ties and relations with previous art movements are investigated. The relation of minimalist approach with contemporary ceramics is evaluated through the artistic practices of artists producing works in this way.

At this point, the works of the artists who avoid the strong effects that source from the nature of material in traditional ceramics and prefer to use the material in the simplest possible status have been described in order to express the minimalist approaches in contemporary ceramics. In this research 12 different artist's works were examined. Although it is observed that the works generally have a simple expression style and reductionist attitude, the difference in the language of expression is remarkable. We can categorize these artistic discourses as follows:

- Pottery

- Architectural works

- Sculptural forms

- Spatial installations

When we evaluate it from a formal and conceptual perspective, it is seen that there are some contradictions in the interaction of Minimal Art which is dominated by new and industrial materials, with a natural material such as ceramic which has very strong traditional references. In fact, we can say that it's not a negative condition and these contradictions and the forcing of this material such 
unconventional way opens up new paths and directions in contemporary ceramic. The minimalist view in the works of the artists draws a new artistic path with its unique expression in contemporary ceramics where there are different perceptions, different searches and discourses.

Furthermore, highly reduced human bodies that Candeğer Furtun made in the late 1980's; geometric abstractions of Kemal Tizgöl containing architectural elements and his early works in which he deals with the phenomena of space-fullness, repetition, movement and mass; sculptural ceramics of Hasan Şahbaz without glaze and decoration, optical oriented works of İsmet Yüksel can be considered as minimalist approaches in Contemporary Turkish Ceramics.

\section{References}

Archer, M. (1997). Art Since 1960, Thames and Hudson, London.

Batur, E. (Ed.). (1995). “avant-garde 1945-1995 “, Sanat Dünyamız Dergisi, YKY, Issue: 59.

Camps, J.P. (2001). "Enrique Mestre Uniting Geometry \& Ceramics", Ceramics Art and Perception, Issue: 46.

Clark, G. (1999). Alev Ebüzziya Siesbye, tranlation: Zeynep Rona, Kaleseramik Sanat Yayınları, Istanbul.

Dewald, G. (2004). Don't say much. On silence, 13.11.2019. https://www.michael-cleff.de/texte/ gabi-dewald-2004/

Meyer, J. (2001). Minimalism, Art and Polemics in the Sixties, Yale University Pres, New Haven and London, China.

Meyer, J. (2002). Minimalism Themes and Movements, Phaidon, Hong Kong.

Mönig, R. (2001). On Michael Cleff, 13.11.2019. https://www.michael-cleff.de/texte/rolandmoenig-2001/

Şahbaz, H. (2006). Modern Seramik Sanatında Minimalizm, Unpublished Postgraduate Thesis, Anadolu University Institute of Social Sciences, Eskişehir/Turkey.

Tizgöl, K. (2008). Sanatta Minimalizm ve Günümüz Seramik Sanatına Yansımaları (Minimalism in Art and Reflection on Contemporary Ceramics), Unpublished Thesis of PhD, Dokuz Eylül University Institute of Fine Arts, Izmir/Turkey.

Vecchio, M.D. (2001). Postmodern Ceramics, Thames\&Hudson, London.

Welch, A. (2006). "Minimalism and Ceramics the Sculptural Perplex of Brian Harper", Ceramics Art and Perception, Issue: 63.

\section{Visual References}

Figure 1: Meyer, J. 2002, p.76

Figure 2: https://www.theguardian.com/artanddesign/jonathanjonesblog/2016/sep/20/carl-andreequivalent-viii-bricks , (19.09.2019)

Figure 3: Archer, M. 1997, p.181 
Figure 4: https://www.slideshare.net/nateabels/week11-art-after1945bsp10 (20.09.2019)

Figure 5: http://enricmestre.com, (17.09. 2019)

Figure 6: Clark, G. 1999, p.66

Figure 7-8: https://bodilmanz.com , (14.09.2019)

Figure 9: http://artscenecal.com/ArtistsFiles/DamW/DamWFile/DamWPics/WDam3.html, (19.09.2019)

Figure 10: http://artscenecal.com/ArtistsFiles/DamW/DamWFile/DamWPics/WDam4. html,(19.09.2019)

Figure 11: http://artscenecal.com/ArtistsFiles/DamW/DamWFile/DamWPics/WDam2.html $(19.09 .2019)$

Figure 12-13: (https://www.michael-cleff.de/portfolio-category/plastiken/ , (14.09.2019)

Figure 14: (https://www.studiointernational.com/index.php/nicholas-rena-the-harmony-of-theyear)

Figure 15-16-17-18: http://www.keneastman.com/20002009 , (08.09.2019)

Figure 19: Tizgöl, K. 2008, p.112

Figure 20: https://www.invaluable.com/auction-lot/fukami-sueharu-b-1947-681-c-42f6054443 , (14.09.2019)

Figure 21-22-23: https://www.doris-kaiser.de/index.php\# (14.09.2019)

Figure 24: http://www.studiopottery.co.uk/profile/David/Binns , (17.09.2019)

Figure 25: Welch, A. 2006, p.53 